\title{
STATES THAT HAVE NOT MET THEIR CONSTITUTIONAL REQUIREMENTS
}

\author{
LLOYD M. SHORT*
}

State constitutional provisions with respect to legislative reapportionment are more honored in their breach than in their observance. This is a rather curious phenomenon in a country which has placed so much store by written constitutions as the sina qua non of popular sovereignty and the rule of law. It is the purpose of this article to examine why such constitutional provisions have not been observed. ${ }^{1}$

\section{The Constitutions}

Our examination immediately leads to a first conclusion-namely, that the constitutional provisions themselves are at fault. They contain incompatible requirements such as the one in Louisiana which, though it establishes the principle of "equal and uniform" representation, fixes a maximum house membership of ror, grants to each parish and to each ward of New Orleans one representative regardless of population thereby automatically apportioning 80 of the seats, and thus leaves only 21 to be distributed purely on the basis of population. ${ }^{2}$

They are inconsistent in establishing the bicameral system of legislative organiza-

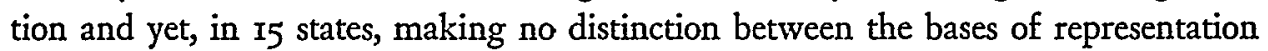
of the two houses of the legislature Differences in size, length of term, and minimum age qualification are hardly sufficient to justify the disadvantages which result from the necessity of passing legislation through two houses. As one writer puts it, "bicameralism presupposes that there will be two distinct representation bases for its construction and utilization"; and, "it is axiomatic that effective bicameralism demands this separateness of base for separate chambers. ..."3 And yet, as this

*A.B. 19x9, LL.D. 1948, Knox College; A.M. x920, Ph.D. 1922, University of Illinois. Professor and Chairman, Department Political Science, and Assistant Dean of the Graduate School, University of Missouri, 1923-I935; Professor of Political Science and Director of the Public Administration Center, University of Minnesota, since 1935 . Author, The Development of National Administrative OrganizatTon in the United States (ig24); (with C. W. Tiller) The Minnesota Commission of AdministraTION AND Finance, I925-I939 (1942). Contributor to periodicals in political science and public administration.

${ }^{2}$ No attempt has been made to canvass carefully the situation in each state. To do so would require thorough studies such as that recently made by Thomas Page for the state of Kansas, Legrsiative Apportionment IN Kansas (unpublished doctoral dissertation, University of Minnesota, 1950). Fortunately, a substantial number of articles, research reports, and monographs dealing with particular states or the states in general have been published in recent years and this writer is indebted to them for the information and conclusions upon which this article is based. To avoid frequent footnoting, sources used will, for the most part, be referred to only in a concluding bibliography.

2 Emmett Asseff, Legislative Apportionment in Louisiana 43 (1950). See also Page, op. cit. supra note $I$, at 338 .

${ }^{3}$ Shull, Revitalizing Representation, 25 Social Science 234, 235 (1950). 
same writer observes, the states are organized internally upon the unitary rather than the federal pattern. Counties, per se, hardly deserve legislative representation in the same manner as states in the national Congress. At times, it is difficult to determine whether the advocates of bicameralism are seeking a justification for its continuance by urging a distinction in the bases of representation or whether they are interested in bicameralism primarily because it offers a means of representing different interests in the body politic. ${ }^{4}$ It is the view of this writer that one of the most powerful deterrents to the spread of unicameralism in the states will be the pressure for compromise in the bases of legislative representation for which bicameralism is perhaps the most convenient though certainly not the only vehicle. $\mathrm{Be}$ that as it may, the failure to use bicameralism for this purpose in the constitutional arrangements of many of the states offers a convenient "out" for legislators and others who are not disposed to favor reapportionment.

In a substantial number of state constitutions counties are accorded representation in one house or the other without regard to or with diminished recognition of population. As population changes have occurred, the disparity between counties and sections of the state has increased markedly so that the principle of county equality appears increasingly untenable.

Other constitutional rigidities which should be mentioned are that no county shall be divided to form a legislative district unless the county is entitled to more than one representative or senator, that county, ward, or precinct lines must be followed in the formation of districts, and that a fixed or maximum number of members in one or both houses shall prevail. The moiety clause in the Michigan constitution is an example of a direct conflict between the requirement of proportionate representation and a maximum number of members in the house of representatives. Obviously, such requirements present obstacles to achieving equality of population even when there is a will to achieve it.

Constitutions also contain such specific requirements with reference to reapportionment and redistricting that they effectively prevent legislative experimentation with other bases of representation such as votes cast in preceding elections, and with multiple-member districts.

Perhaps the most obvious fault of state constitutional provisions relative to reapportionment is that, whatever may have been the reasons for their adoption, they no longer square with the "facts of life." Granted the strong support which can be marshalled for the theory of representation on the basis of population, those whose responsibility it is to put that theory into operation are, for a variety of reasons which will be examined later, not disposed to do anything about it. Likewise, as will be noted later, there seems to be no effective way of forcing them to do so. Perhaps we have too often, in our discussion of this subject, assumed without sufficient justification that "the people" want them to do something about it. At any rate, we must now face a more fundamental obstacle.

- PAGE, op. cit. supra note $\mathrm{r}$, at 338 . 
If present state constitutional provisions are unworkable, inconsistent, and outdated, why are these constitutional barriers to reapportionment permitted to continue? The answers to this question are pretty obvious to anyone familiar with recent attempts to amend or revise state constitutions. The amending process, frequently made difficult for the purpose of providing constitutional stability, stands in the way. Except in those few states which permit the use of the initiative and referendum, proposed amendments must run the gauntlet of a hostile or indifferent legislature and require an extraordinary majority in both houses before they can be submitted to the voters. If they pass this first hurdle, they must then often win an extraordinary majority of the popular vote to become a part of the constitution. Constitutional conventions also are difficult to achieve and, as has been so recently illustrated by the example of New Jersey, they may be prevented from dealing with this major issue by a legislatively imposed restriction incorporated in the act or resolution by which the question of calling a convention is submitted to and approved by the voters. A recent attempt in Minnesota to secure favorable legislative action upon a proposal to submit to the people the question of calling a constitutional convention was unsuccessful, at least in part, because of the fear of some legislators that a convention, once called, would in some way effect a change in the present apportionment and districting.

\section{THe CourTs}

A second answer to our main question, by no means unrelated to the first, is that whatever may be the constitutional requirements for reapportionment, there is no effective judicial remedy if those requirements are not observed. It is customary for citizens of the United States to assume that the courts are the ultimate guardians of our written constitutions and that the acts of the legislative and executive branches of the government are subject to judicial review. The state courts have quite generally agreed to pass upon the constitutional validity of legislative reapportionment and redistricting acts, although granting to the legislatures a wide range of discretion in recognition of both the political and the practical difficulties involved. Typical of judicial attitude on this point is the followng portion of a Wisconsin supreme court decision: ${ }^{\sigma}$

... perfect exactness in the apportionment, according to the number of inhabitants, is neither required nor possible. . . . If, as in this case, there is such a wide and bold departure from this constitutional rule that it cannot possibly be justified by the exercise of any judgment or discretion, and that evinces an intention on the part of the legislature

${ }^{8}$ State v. Cunningham, 8 I Wis. $440,484,51$ N. W. 724,730 (I892). (Italics supplied.) For another example of judicial acceptance of legislative discretion concerning apportionment, see the New York cases involving the so-called "second ratio." Matter of Sherrill v. O'Brien, I88 N. Y. I85, 8x N. E. 124 (1907), and Matter of Fay, 29x N. Y. 198, 52 N. E.2d 97 (1943). Admittedly the courts often face the dilemma that if they declare a reapportionment or redistricting act unconstitutional they therefore, for the time being at least, revive the previous act which may involve even greater inequalities. 
to utterly ignore and disregard the rule of the constitution in order to promote some other object than a constitutional apportionment, then the conclusion is inevitable that the legislature did not use any judgment or discretion whatever.

A Minnesota case carries this attitude of judicial unwillingness to interfere with legislative discretion a step further. When called upon in 1945 to review a reapportionment act passed in Igr3 the constitutionality of which had once been affirmed, the court refused to take into account the fact that in the intervening three decades the population of the legislative districts had become grossly unequal. The court said: ${ }^{6}$

It is our opinion that a reapportionment act, valid when enacted, may not be held unconstitutional by reason of subsequent changes in the relative population of the districts, and that it continues in force until superseded by a valid act.... The remedy [for gross inequality] lies in the political conscience of the legislature, where lies the burden of the constitutional mandate. It is not within the province of this court to prompt the action of that conscience. It is usually sensitive enough to promptings from the electorate.

The court presumably is to be excused for its failure to point out how an electorate, denied the representation in the legislature to which it is constitutionally entitled, can effectively prompt a legislative conscience that has been dulled by selfinterest and a conviction that what the constitution calls for is unwarranted and unwise.

Apparently, a more precise constitutional definition of reapportionment and redistricting standards is necessary if the state courts are to be counted upon in the future to aid materially in avoiding legislative action that violates those standards. This, of course, does not solve the problem of legislative inaction. An alternative is to make reapportionment an administrative rather than a legislative act. Both of these steps have been taken in some jurisdictions. The new Missouri constitution, adopted in 1945 , substitutes a commission for the legislature as the districting body and provides that no senatorial district may vary by more than 25 per cent from a quotient computed by dividing the total population of the state by the number of senators (34).

\section{III}

\section{The Legislatures}

Most students and observers of state government regard the state legislatures themselves as the main reason why constitutional provisions regarding reapportionment have not been carried out. In fact there are some who would go so far as to say that unless and until the job is taken entirely away from the legislative body, it

\footnotetext{
${ }^{\circ}$ Smith v. Holm, 220 Minn. 486, 491-492, 19 N. W. 2d 914, 916 (1945). The Wisconsin supreme court took a substantially similar position in the case of State ex rel. Martin v. Zimmerman, 249 Wis. IoI, 23 N. W. 2d 6ro (1946). A somewhat more sympathetic attitude was taken by the Washington supreme court in upholding the use of the initiative and referendum for purposes of reapportionment and redistricting. The court in its opinion took cognizance of the continued failure of the lcgislature to follow the constitutional mandate. State ex rel. Miller v. Hinkle, 156 Wash. 289, 286 Pac. 839 (1930).
} 
will not get done, ${ }^{7}$ and several states as noted elsewhere in this symposium have either substituted administrative officers, boards, or commissions, or have provided them or the initiative and referendum as alternative methods of reapportionment. Specifically, why have state legislatures found this important task so difficult to accomplish? An examination of studies of the problem in many states reveals substantial agreement in the answers to this question.

Admittedly the task is a tough one. Hallie Farmer, in her chapter on Apportionment in Alabama, begins by recognizing that "one of the most difficult problems with which any state must deal is that of securing an equitable arrangement of legislative districts. Few states can be said to have arrived at a satisfactory solution to this problem. ..."8 But granting the difficulties, and observing as we have above that constitutional provisions are often at fault, the state legislatures have made a pretty poor record on this assignment. Their "sins" are both of commission and omission, but our concern here is mainly their inaction.

Undoubtedly, the rural-urban controversy is in the background of nearly every apportionment proposal. ${ }^{9}$ In those states where the constitution makes population the basis of representation in both houses, as noted above, and where one or two large cities are involved, the problem is particularly acute. A goodly number of the states have at least partially met the problem through constitutional limitations upon the representation of single counties in one or both houses of the legislature or, alternatively, have required that each county or other political subdivisions have at least one senator or representative regardless of population. Where such constitutional limitations upon urban areas are found, the reapportionment struggle becomes an issue of constitutional amendment or revision but even here, as we noted above, the legislature is often in a dominant position.

Why do legislators from rural areas favor such constitutional limitations or, conversely, oppose granting equality of representation on the basis of population? Several factors appear to enter in, some of which may be mere rationalizations. The advantage of political power now possessed by rural constituencies is not to be given up without a struggle. Such advantage is particularly useful in the matter of determining tax rates and new sources of tax revenue, the formulae and amounts of state grants-in-aid, and the allocation of shared taxes. Individual legislators are apprehensive over the personal consequences of redistricting, including changes in district boundaries, enlarged areas for campaigning, the possibility of having to run against each other, and the shifting of party strength. The people "back home" prefer small legislative districts where the legislator is better known and more readily

\footnotetext{
"Waldo Schumacher in his article on "Reapportionment in Oregon," quotes a delegate to the Oregon Constitutional Convention of 1857 as saying: "I am satisfied from my experience in this country that the legislative assembly can never-will never-justly and equitably apportion' the representation of the several counties of the state if left to them." 3 WESTERN PoL. Q. 428 (1950).

${ }^{3}$ The Legislative Process in Alabama (Bureau of Public administration, University of AlaBAX(A, 1949) I7.

${ }^{\circ}$ Schumacher, supra note 7 , at 428 .
} 
accessible. Increased representation from urban areas, they insist, carries with it the dangers of radicalism, machine politics, and corruption.

Closely akin to and sometimes a part of the rural-urban issue is the matter of sectional and party rivalries which in turn may be grounded upon economic and racial interests. ${ }^{10}$ Whole sections in a state with static, declining, or slowly increasing populations oppose giving proportionate representation to other sections where more rapid population increases occur. Even in fabulous California, northern urban centers were willing to accept a constitutional amendment limiting representation from urban counties in order to "contain" more rapidly growing southern urban areas. "Black belt" counties resist either constitutional change or statutory action which will reduce representation from the "intelligent and wealthy portion of the state."11 The somewhat intangible but nonetheless real factor of out-state pride makes it difficult for legislators to accept a reapportionment which would give a single city as much representation as the remainder of the state. The same set of facts by which organizations such as the United States Conference of Mayors point so convincingly to the under-representation of urban areas is used by rural legislators to satisfy themselves and their constituents that reapportionment and redistricting should not be undertaken unless and until constitutional guarantees of continued rural dominance can be assured.

IV

\section{Public Attitudes and Partirs}

There is ample evidence that, in many of their attitudes and points of view, rural legislators are reflecting group mores and thought patterns which prevail quite generally even among some of their fellow members from the cities. One of the most persistent opponents of constitutional revision in Minnesota has not hesitated to create apprehensions among his fellow legislators over the specter of reapportionment even though he comes from a legislative district that is grossly under-represented. The President of the National Association of Real Estate Boards is quoted from an address of several years ago as follows: ${ }^{12}$

Today the greatest threat to democratic institutions, to the republican form of government, and ultimately to freedom itself, lies in our big cities. They are populated for the most part with the mass-man, devoid of intelligence, and devoid of civic responsibility. He talks only about rights and has no conception of responsibilities. He will vote for anyone who offers him something for nothing. Whether it be subway fares at halfprice or public housing at one-third price. ... Our one hope of survival as a free country is that rural and semi-rural areas still dominate most of the state legislatures through their representatives and still dominate the House of Representatives at Washington. Our best hope for the future is to keep it that way.

\footnotetext{
${ }^{10}$ PAGE, Op. cit. supra note $\mathrm{I}$, at $8 \mathrm{I}-\mathrm{I} 19$. See also a discussion of factors in reapportionment in California in the Report of the Assembly INTERIM Committee on Elections and Reapportionnent 33-53 (Sacramento, June 21, 195I).

${ }_{11}$ FARMER, op. cit. supra dote 8, at 22-30.

${ }^{12}$ In August N. Renner, Legiszative Reapportionment in Wisconsin (unpublished M. S. thesis, University of Wisconsin, 1948 ), also quoted by PAGE, op. cit. stupra note 1 , at 332.
} 
This somewhat extreme view of the political frailties of the urban dweller seems to express pretty well the sentiments of many both within and without our state legislatures. At least it serves as a most convenient rationalization for the legislator from either a rural or an urban district who opposes reapportionment on other more immediate and tangible grounds.

Partisan advantage in the maintenance of the status quo is another powerful deterrent to reapportionment and redistricting, especially the latter. The many evidences of district boundary manipulation, motivated by partisan interest, provide ample justification for reluctant legislators, whose party or caucus stands to lose strength by any change in the existing apportionment or districts, to drag their feet if not openly oppose such change. What often appears on the surface to be a concern for political virtue is in reality a desire to protect personal and party status.

The disinclination of even the urban voter to become greatly concerned over the matter of under-representation in his state legislature, as evidenced by the failure of popularly initiated measures in Oregon and California, suggests that not unlike his rural brother (or father) he is not sure but that his state will be better governed by rural than by urban senators and representatives. Or perhaps his vote is influenced by the better organized and financed campaigns of economic pressure groups, most of which are to be found in opposition to increased urban representation or the disturbance of the status quo. ${ }^{13}$

\section{$\mathrm{V}$ \\ Ways Out of Our Diremasa}

In concluding this attempt to draw upon the experiences of the states within the past decade or so in the search for answers to the question why constitutional requirements for reapportionment have not been met, it may be well to raise the further question, to wit, what if anything should be done about it? Perhaps a first and acceptable attempt to answer this latter question is to examine what, if anything, has been done about it. Here we find at least three approaches to the problem. First, there are the efforts to find a more generally acceptable formula for representing people and interests in our state legislatures. In general, these efforts have taken the form of a compromise, often using the bicameral legislative system to make it possible. Thus, the new Missouri constitution undertakes to insure proportionate representation in the senate while making a concession to the rural areas through a ratio system of representation in the house which gives each county at least one representative and which gives to more populous counties considerably less than proportionate representation. The Minnesota Constitutional Commission, reporting

${ }^{13}$ Dean McHenry points out that in California "urban-rural rivalry for legislative representation is (in some ways) a smokescreen for another type of cleavage. Certain business interests in the state have found it easier to make their influence felt in the legislature through senators from rural areas. Privately owned utilities, banks, insurance companies, and other concerns with crucial legislative programs have discovered some "cow county' legislators more responsive to their demands and less committed to contrary points of view on key social and economic questions than are urban representatives." Urban vs. Rural in California, 35 Nat. Munic. Rev. 350, 353-354 (1946). 
in 1948 , took cognizance of the fact that, although the present constitution requires apportionment on the basis of population in both senate and house, no reapportionment measure has been passed since rgr 3 despite more or less constant efforts to do so. Consequently, it recommended an amendment which was designed to insure proportionate representation in the house while limiting representation in the senate to not more than one-eighth from any one county nor more than one-fourth from any two contiguous counties (obviously aimed at the Minneapolis-St. Paul metropoli$\tan$ area).

Second, there are the attempts to narrow the range of legislative discretion and to make the process of reapportionment and redistricting more nearly automatic. The use of the latter device undoubtedly has been encouraged by the relatively successful operation of the automatic reapportionment system introduced by Congress in 1929 for the national House of Representatives. ${ }^{14}$ Admittedly, the former is not apt to be particularly successful in achieving the desired result unless it is coupled with the latter or with some other device calculated to insure action of some sort.

Third, there are the more drastic actions designed to take from the legislatures the power to reapportion and redistrict or to provide alternative methods if the legislatures fail to act. This attack on the problem has the further merit of overcoming judicial inability or unwillingness to intervene to insure a faithful observance of constitutional requirements, since the task is given to an administrative agency acting in a more nearly ministerial capacity. ${ }^{15}$

It is the judgment of the present writer that, given the difficulties of constitutional change already noted in this article, present-day state legislatures are most likely to accept a compromise proposal which incorporates aspects of all three of these approaches-namely, some limitation on the representation of urban areas in at least one house, a percentage spread beyond which the population range of singlemember legislative districts may not vary, and an alternative method of apportionment and redistricting if the legislature fails to act at its first session following each decennial census.

Admittedly, such a course of action begs the more fundamental question as to the most appropriate base or bases of representation in our state legislatures. This is an age-old question which has concerned political theorists, past and present. Present day practices are an admixture of political ethics, tradition, convenience, prejudice, and self-interest, both enlightened and otherwise. One is encouraged to think that we are on the threshold of a new era of research and investigation of political and human behavior whereby we may be able to cast some new light upon, if not prove or disprove, the contentions of those who hold to certain time-honored views about

1446 STAT. 26 (1929), as amended, 2 U. S. C. \$2a (1946).

15 Elizabeth Durfee, after noting the advantages of an independent board, concludes: "In no other way can the duty of reapportionment be enforced." Representation in the Legislature: A Study of State Constitutions, $43 \mathrm{MrCH}$. L. Rev. 1091, 1103 (1945). Texas is the latest state to utilize this method of dealing with the problem of legislative inaction. Sce McClain, Compulsory Reapportionment, $4^{\circ}$ Nat. MUNic. Rev. 305-307, 324 (195I). 
the characteristics and tendencies of voters wherever they may reside. It may take a "rotten-borough" condition much worse than now prevails in most of our states, a dramatic sit-down strike of urban taxpayers, an unexpected new judicial attitude of willingness to come to grips with the situation, or an increased awareness of citizens to the grave consequences of failure to provide a truly representative assembly, to provide the necessary impetus to action on this problem. The student of government and politics, however, has good reason to place his trust ultimately in the acquisition of new knowledge and insights which can be accommodated to the exigencies of the moment by men of intelligence and good will. The forthcoming report of the Committee on American Legislatures of the American Political Science Association may prove an important beginning in this direction.

\section{Selected Bibliography}

Alabaia Legislative Reference Service, Reapportionment (Montgomery, 1950).

Assegf, Legislative Apportionment in Louisiana (Louisiana State University, I950).

Barclay, Reapportionment in California, 5 PAC. Hist. Rev. 93 (1936).

- The Reapportionment Struggle in California in 1948, 4 WeSTERN PoL. Q. 313 (1951).

Brannon, Missouri's Apportionment Key, 35 Nar. Munic. Rev. I77 (1946).

California (State). Report of the Assembly Interim Committee on Elections and Reapportionment (SACramento, JUNe 2I, 195I).

California, University of. Legislative Apportionment (Bureau of Public Administration, BerkeLEY, I94I).

Dorweiler, Minnesota Farmers Rule Cities, 35 Nat. Munic. Rev. I15 (1946).

Dovezl, Apportonment in State Legislatures: Its Practice in Fiorida (Bureau of Economics and Business Research, College of Business Administration, University of Florida, 1948).

Durfee, Repiesentation in the Legislature: A Study of State Constitutions, 43 Mrch. L. Rev, rogr (I945).

Farmer, The Legislative Process in Alabama (Bureau of Public administration, University of AlabaMa, 1949).

Faust, Manual on Legislative Article for the Missouri Constitutional Convention of i943 (Statewide Committee for the Revision of the Missouri Constitution, Columbia, i943).

Greenfield, Legislative Reapportionment (Bureau of Public Administration, University of CaliFORNIA, BERKELEY, I95I).

Harvey, Some Problems of Representation in State Legislatures, 2 WESTERN PoL. Q. 265 (1949).

Hawait, University of. Constitutional Provisions for Legislative Apportionment and Reapportionment (Legislative Reference Bureau, I948).

Hubbard, In the Matter of the Problem of Reapportionment Generaliy and a Proposed Amendment to Article III of the Constitution, Legtslative Document No. 3r, Preliminary Report to the Joint Legislative Committee on Reapportionment (Albany, 1950).

Illinois Legislative Council, Research Department, Reapportionment in Illinois: Congressional and State Senatorial Districts, Research Report No. 3 (1938).

- Reapportionment in Illinois, Publication No. 66. (Springfield, 1945).

Iverson and Greene, The Apportionment of Legislative Seats, il Papers on Constitution Revision (Bureau of Public Administration, University of Tennessee, Knoxville, I947).

Key, Procedures in State Legislative Apportionment, 26 AM. Por. Scr. REv. 1050 (1932).

Lancaster, Rotten Boroughs and the Connecticut Legislature, I3 NAT. Munic. Rev. 678 (I924).

Louisiana (State). Law Institute. Central Research Staff Constitution Revision Project. Bull. No. 12, The Legistature-Apportionment (1947).

MacCorkle, Texas Apportionment Problem, 34 NAt. Munic. Rev. 540 (1945).

MacNeil, Urban Representation in State Legislatures, i 8 STate Government 59 (I945).

McClain, Comptulsory Reapportionment, 40 Nar. Munrc. Rev. 305 (I95I). 
McHenry, Urban Vs. Rural in California, 35 Nat. Munic. Rev. 350 (1946).

Mínnesota (State). Legislative Research Committee. Publication No. 36, Legislative ReapporTIONMENT (ST. PAUL, r950).

Moore, Legislative Reapportionment, [1949] Wis. L. REv. 76I.

Neuberger, Our Rotten Borough Legislatures, 86 SURvex 53 (1950).

New York (State). Constitutional Convention Committee, Problems Relating to Legislative Organization and Powers 224 (Axbany, r938).

Orzahoma Constitutional Survey Committee. Legislative Apportionment in Oklahoma, ConstitutJoNal Study No. to (NorMan, I948).

Okzahoma, UniverstTy of. Buread of Government Research. Legislative Apportionment in ORLAHOMA (I95I).

Page, Legislative Apportionment in Kansas (unpublished Ph.D. thesis, University of Minnesota, I950).

Schumacher, Reapportionment in Oregon, 3 Western Polit. Q. 428 (1950).

Shull, Reapportionment: A Chronic Problem, 30 Nat. Munic. Rev. 73 (194r).

- Legislative Apportionment and the Law, 18 Temp. L. Q. 393 (I944).

- Revitalizing Representation, 25 SociaL ScIENCE 234 (1950).

Thornton, Oklahoma Cities Weakened, 35 Nat. Munic. Rev. 295 (1946).

U. S. Conference of Mayors. Brochure entitled "Government of the People, by the Pcople, for the People (1948)," and Digest of Newspaper Editorials and Articles under the caption "Representation Is the Basis of Our Structure of Government (1948)."

Walter, Reapportionment and Urban Representation, I95 ANNals 11 (1938).

- Representation of Metropolitan Districts, 27 Nat. Mundc. REv. 229 (1938).

- Reapportionment of State Legislative Districts, 37 ILl. L. REv. 20 (I942).

Wisconsin Legistative Reference Library. Research Report No. iox. Legislative Apportionment in Wisconsin (Madison, 1950).

Webster, Voters Take the Law in Hand, 35 Nar. Munic. Rev. 240 (1946). 